\title{
THE TURNOVER RATE OF SERUM ALBUMIN IN MAN AS MEASURED BY I'131-TAGGED ALBUMIN ${ }^{1}$
}

\author{
BY KENNETH STERLING 2 \\ (From the Biophysical Laboratory and the Department of Medicine, Harvard Medical School, \\ and the Medical Clinic, Peter Bent Brigham Hospital, Boston, Mass.)
}

(Submitted for publication June 20, 1951; accepted August 13, 1951)

The biological importance of serum albumin makes information on its metabolism of value. In the present work the turnover rate of serum albumin in man was studied by following the disappearance from the circulation of albumin labelled with radioiodine.

Previous clinical investigations (1-3) have dealt with the metabolic fate of massive intravenous infusions of concentrated albumin, employed to increase the patient's albumin stores. In contrast, the subjects in the present study received only 1 to $10 \mathrm{mg}$. of labelled protein. This minute amount of albumin could not have any significant effect upon the serum albumin concentration or upon protein metabolism, thus permitting studies on the subject in a steady state.

Intravenous injection of $I^{181}$-tagged albumin was followed by a relatively rapid initial fall in the radioactivity of the circulating plasma. After approximately two days the plasma radioactivity diminished more gradually. The rate of this gradual decline was considered to represent the rate of replacement of tagged by untagged protein, or the turnover of serum albumin.

\section{METHODS}

Iodination of albumin. The albumin molecule was labelled with an average of 2-3 iodine atoms per molecule. This ratio was selected to minimize alterations from the native state of the protein. The iodine was bound by tyrosine groups forming monoiodo-tyrosine under the conditions described by Hughes and Straessle (4) for iodination of albumin with small amounts of iodine.

Radioactive iodination with $\mathrm{I}^{\mathrm{m}}$ followed the procedure of Latta (5). All operations were performed in the cold $\left(4-10^{\circ} \mathrm{C}.\right)$.

Dialysis was carried out to remove unbound $I^{120}$, first against isotonic $\mathrm{KI}$ solution, then against running de-

1 This work was supported in part by the United States Atomic Energy Commission.

2 This work was done during the tenure of a U. S. Public Health Service Postdoctorate Research Fellowship. mineralized water ( 36 hours), and finally against isotonic saline solution. The amount of free radioiodine remaining after dialysis was determined as a rapid approximation by comparing the radioactivity of appropriately diluted protein solution with that of the supernatant after trichloroacetic acid precipitation. The trichloroacetic acid supernatant was diluted 1:25 to prevent acid attack on planchets. The supernatants did not exceed $2 \%$ of the total radioactivity. Subsequent determinations based on assay of supernatants after precipitation by specific antisera gave slightly lower values for unbound radioactivity.

To each lot of dialyzed tagged albumin for use in human studies a drop of penicillin and of streptomycin were added; sterility was verified by culture.

Much of the labelled protein employed was prepared by Abbott Laboratories ${ }^{3}$ by similar methods. Instead of freeing the albumin of unbound radioiodine by dialysis, the material was passed through a resin column (IRA-400 pre-treated with $1 \mathrm{~N} \mathrm{HCl}$ ) which achieved comparable results rapidly.

All material regardless of source was subjected to the same testing to establish its similarity to native albumin. The tests undertaken were ultracentrifugal analysis, immunologic specificity, and disappearance curves in rabbits with immunochemical controls.

Ultracentrifugal analysis. 4 Satisfactory homogeneity on ultracentrifugal analysis was the most sensitive criterion that the labelled albumin was not significantly changed from the starting material. Improperly handled or too heavily iodinated protein exhibited faster sedimenting components in addition to the characteristic albumin peak with sedimentation constant approximating 4.5 $S$. The more rapidly sedimenting material represented aggregated albumin molecules with consequently higher molecular weight (Figure 1). Labelled protein showing such alteration was discarded.

Immunologic specificity. Quantitative precipitin tests were done on the labelled protein concomitantly with standards prepared from the starting material. The

\footnotetext{
3 Department of Radioactive Pharmaceuticals, Abbott Laboratories, North Chicago, Ill.

4 Courtesy of Professor J. L. Oncley, University Laboratory of Physical Chemistry Related to Medicine and Public Health, Harvard University. Analyses were performed by Mr. Charles Gordon under the supervision of Dr. Oncley. An air-driven ultracentrifuge with a modified Philpot optical system was used. The speed employed was 54,000 r.p.m. (approximately $180,000 \mathrm{~g}$ ).
} 
tagged albumin showed unaltered behavior as a specific antigen in agreement with previous reports $(6,7)$.

Immunochemical tests. The quantitative precipitin technique as described by Gitlin (8) was employed in determining disappearance curves of human albumin injected into rabbits as well as in routine albumin measurements on human plasma samples. Howe sodium sulfate fractionations were also done on human plasmas as a preliminary approximation.

Specific precipitates were obtained by adding $1.0 \mathrm{ml}$. of antigen solution (unknown or standard) to $1.0 \mathrm{ml}$. of rabbit antiserum against human serum albumin. The antigen solutions had been diluted so that reactions occurred in the zone of antibody excess, which was confirmed by tests on the supernatants. After washing with saline solution $\left(4-10^{\circ}\right.$ C.) the specific precipitates were dissolved in $0.25 \mathrm{~N}$ acetic acid and the optical densities measured with the Beckman quartz spectrophotometer

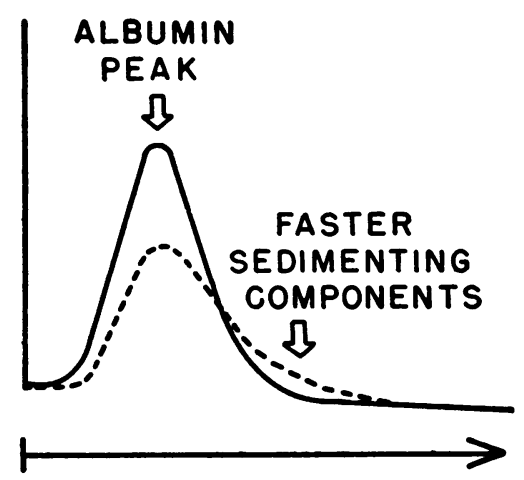

Fig. 1. Schematic Diagram of Ultracentrifugal Patterns

Comparison between two lots of $\mathrm{I}^{11}$-tagged albumin. Dotted line (Lot No. 1) shows abnormal pattern. Solid line (Lot No. 4) reveals no significant alteration from native albumin.

at $277 \mathrm{~m} \mu$. Figure 2 illustrates a curve of simultaneously determined antigen standards against which the duplicate unknown solutions were read.

Antisera were obtained from rabbits which had received three weekly subcutaneous injections of approximately 70 mg. of human serum albumin suspended in aluminum hydroxide. Crystalline human albumin was the most satisfactory antigen for the production of antisera of high specificity. As a further assurance of specificity, the antisera were absorbed with a mixture of human globulin preparations (Cohn's Fractions I, II, and III).

The albumin values for human plasma samples by the precipitin technique were within $10 \%$ of the results of electrophoretic analyses. ${ }^{5}$

Disappearance curve of $I^{18}$-tagged human albumin in the rabbit. As a preliminary step it was necessary to test the assumptions :

${ }^{5}$ Courtesy of Dr. Walter F. Lever and Miss Alice Blaney.

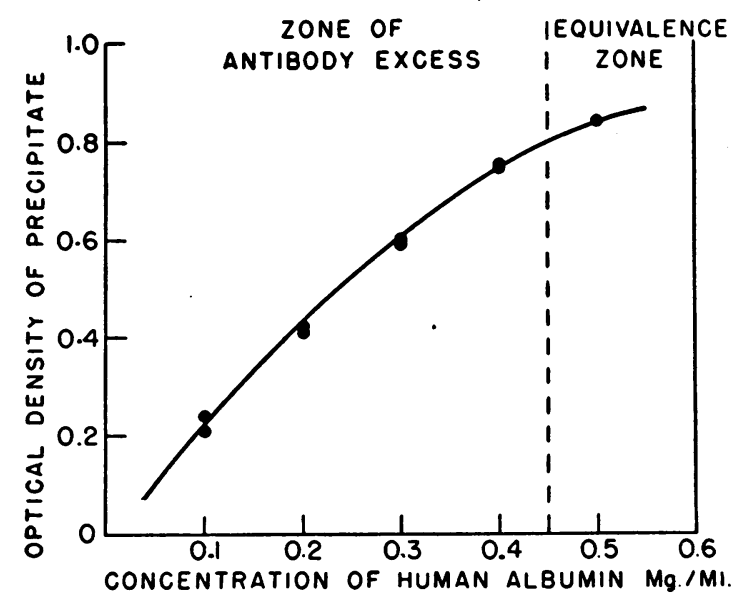

Fig. 2. Standard Curve for Quantitative Precipitin TEST-Gituin's METhOD

(Optical densities of dissolved specific precipitates at $277 \mathrm{~m} \mu$.)

The points represent readings on duplicate specific precipitates obtained from standards of known albumin concentration. Duplicate unknown solutions were determined simultaneously and read against the standard curve.

(1) that $\mathrm{I}^{13}$-tagged albumin remained labelled in vivo throughout the existence of albumin as an intact molecule.

(2) that the labelled protein behaved in vivo like native protein.

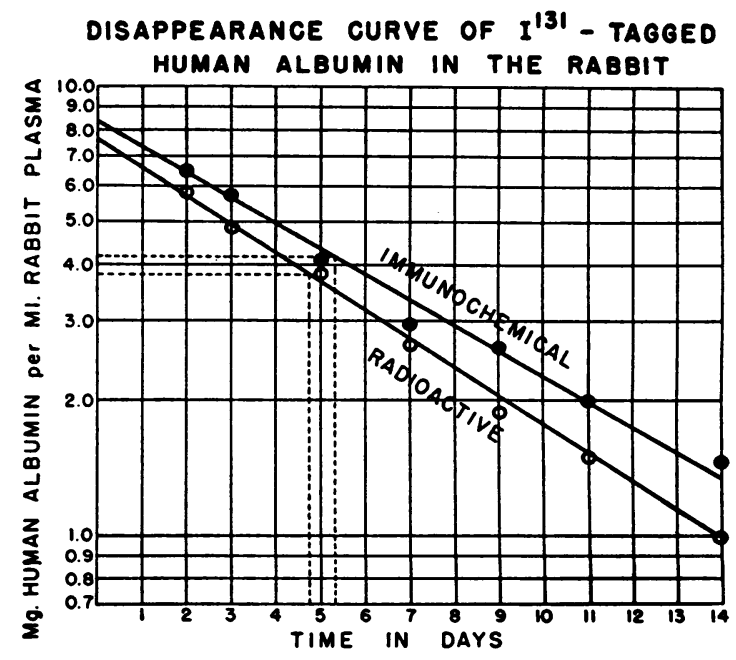

Fig. 3a. Semi-Logarithmic Plot of Disappearance Curves Obtained by Radioactive and Immunochemical. Determinations on Aliguots of the Same Plasma SAMPLES

The half-time of albumin turnover is obtained graphically as shown by the horizontal and vertical dotted lines. 


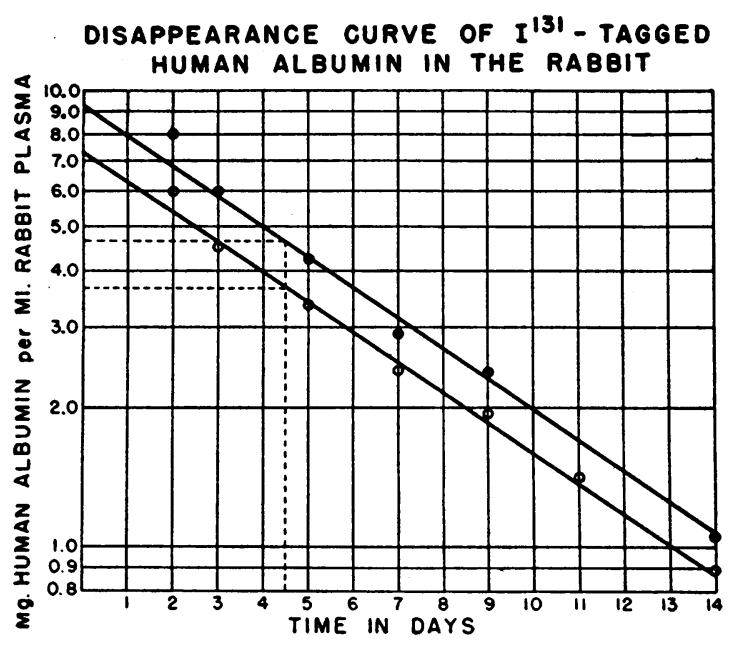

Fig. 3b

Semi-logarithmic plot.

Immunochemical determinations

O Radioactive determinations

The injection of labelled human protein into a foreign species (rabbit) permitted comparison between disappearance curves obtained by radioactive and immunochemical determinations on aliquots of the same plasma samples.

Minute amounts $\left(1-10 \mathrm{mg}\right.$.) of $I^{13}$-tagged human albumin were mixed with thousandfold greater quantities of native human albumin. The mixture was injected intravenously into rabbits and plasma samples were collected on alternate days for approximately two weeks.

Radioactive assays on the plasma samples gave the disappearance curve of the labelled albumin. The immunochemical tests gave the curve of the native human

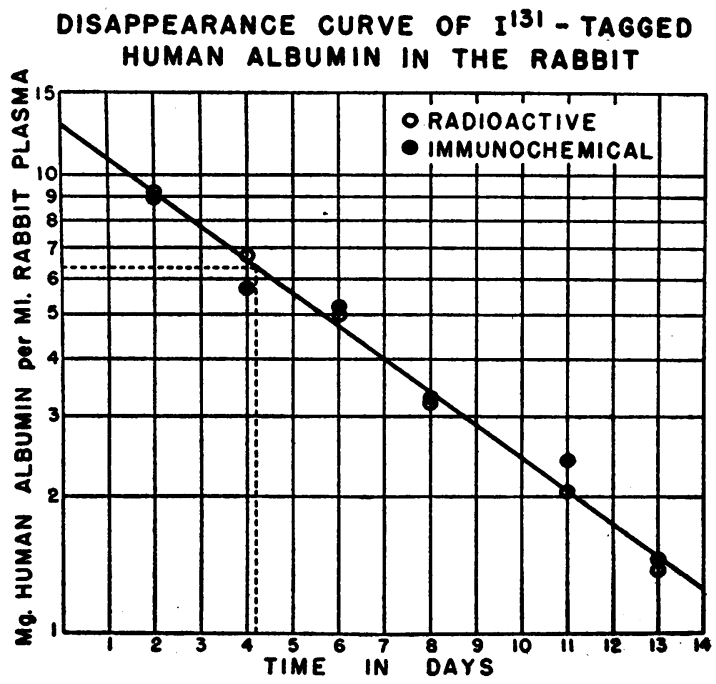

FIG. 3c

Semi-logarithmic plot. albumin, since the amount of labelled albumin was negligible in comparison. The tagged and untreated human proteins were thus followed simultaneously in the same rabbit.

The approximation (Figures $3 a$ and $3 b$ ) and even identity (Figure 3c) of these curves indicated close similarity of behavior of the tagged and native proteins in vivo, at least with respect to disappearance from the circulation. The results also demonstrated the stability of the isotopic label. Similar findings have been reported by Gitlin and associates (9), Knox and Endicott (7), and Dixon, Bukantz and Dammin (10). Gitlin and coworkers (9) have discussed possible reasons for the imperfect correspondence between the two curves.

By way of contrast, the behavior of proteins labelled with another isotope, $\mathrm{Cr}^{\text {s1 }}$, is illustrated (Figure 4).

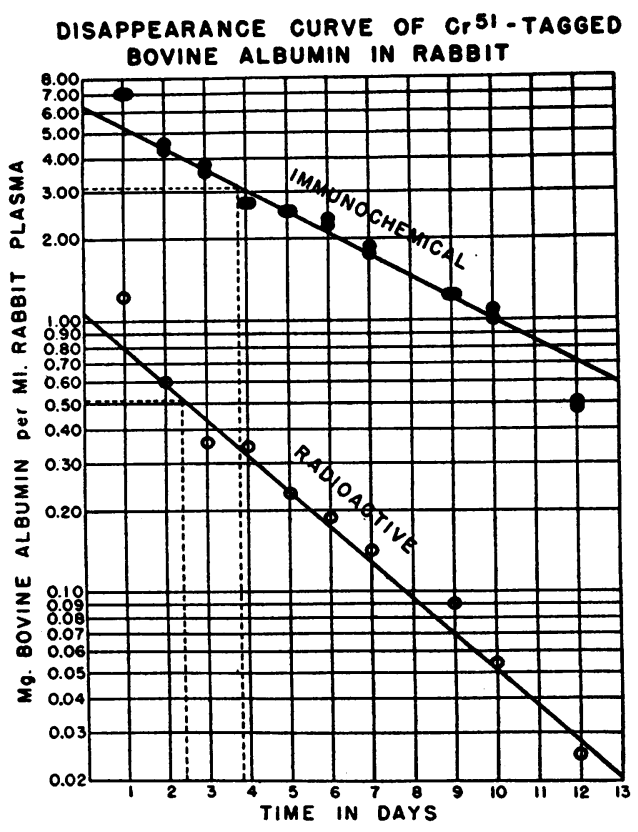

FIG. 4

Semi-logarithmic plot.

Although radioactive chromium was firmly bound by proteins in vitro (11), it proved to be an unstable tag in vivo. In repeated experiments a wide discrepancy occurred between the radioactive and immunochemical curves (Figure 4). Moreover, radioactive assays on the supernatants after specific precipitation by antisera revealed most of the plasma radioactivity in the supernatants from Day 4 on. This indicated a transfer of the chromium from the injected labelled protein to the rabbit's own plasma proteins. The protein studied was crystalline bovine albumin (Armour) labelled with 0.5 chromium atom per molecule (11); on ultracentrifugal analysis it showed no change from the starting material.

In the Im-tagged albumin experiments in rabbits radioactive assays were done on both the supernatants and 
specific precipitates of the plasma samples. Most of the plasma radioactivity was recovered in the specific precipitates, while the supernatants contained traces (mean of $5 \%$ ). These measurements were approximations because of low radioactivity after dilution of plasma samples for the immunochemical tests.

Radioactive assay. Counting was done in the windowless flow proportional counter designed by Robinson (12). Duplicate $1 \mathrm{ml}$. plasma samples were dried at room temperature in planchets containing detergent (a few grains of Lakeseal). Relatively constant dry weight of plasma from a given subject obviated the need for selfabsorption corrections. Initially drawn plasma from each subject was added to radioactive standards and to dried $1 \mathrm{ml}$. urine samples to make them comparable with the direct plasma radioactivity determinations. Appropriately diluted aliquots of the injected iodo-albumin were used as radioactive standards. Corrections for radioactive decay were made when necessary. Plasmas from each subject were counted within a few hours at the end of the study. The counts exceeded ten times the background. The probable error of counting was less than $1.5 \%$.

Radiation dosage. The routine administration of 20 microcuries of $\mathrm{I}^{20}$ as intravenous iodo-albumin approximated a total dose of $0.22 \mathrm{rep}$ in a $70 \mathrm{~kg}$. man on the conservative assumptions of no excretion and localization of radioactivity in the extracellular fluid. ${ }^{\circ}$

Human studies. The albumin turnover was studied in 21 normal male medical students. The studies were carried out with simultaneous groups of five or more normals. The subjects took a diet adequate in protein and calories, and body weight was stable. Determinations of serum albumin at the beginning and end of the two week studies showed no significant changes (mean difference $0.2 \mathrm{gm}$. $\%$ ). The subjects were therefore considered to be in a steady state with regard to serum albumin concentra-

- The equations and data of Marinelli, Quimby, and Hine (13a) and Marinelli (13b) were employed in calculation of the dosages $D_{\gamma}$ (gamma-rays) and $D_{\beta}$ (beta-rays). The constants, $K_{\gamma}$ and $K_{\beta}$, were from Marinelli (13b) based upon more recent knowledge of the disintegration scheme of $\mathrm{I}^{131}$.

where $K_{\gamma}=0.66$ for $I^{131}$

$$
\mathrm{D}_{\gamma}=\mathrm{K}_{\boldsymbol{\gamma}} \mathrm{Cg}_{\mathrm{g}}
$$

$\mathrm{C}=$ concentration in microcuries per gram

$\mathrm{g}=$ geometrical factor based on the human trunk as a cylinder. $\mathrm{g}=314-4140 \mu=190$, where $\mu$ is the linear gamma-ray absorption Hence $D_{\gamma}=125 \mathrm{C}$. coefficient. For $I^{121} \mu=0.03$ per $\mathrm{cm}$. water.

where $K_{\beta}=127$ for $I^{131}$.

$$
\mathrm{D}_{\beta}=\mathrm{K}_{\beta} \mathrm{C},
$$

Hence, $D_{\beta}=127 \mathrm{C}$. However, $D_{\beta}$ must be multiplied by 5 if the isotope is confined to extracelluiar fluid which is approximately one-fifth the body weight. $5 \mathrm{D}_{\beta}=635 \mathrm{C}$. Total effective dose in rep

$$
=D_{\gamma}+5 D_{\beta}=125 \mathrm{C}+635 \mathrm{C}=760 \mathrm{C} \text {, }
$$

where $\mathbf{C}=$ microcuries administered per gram body weight.

Then if 20 microcuries be given to a $70 \mathrm{~kg}$. man,

Total effective dose in rep $=760 \mathrm{C}=\frac{760 \times 20}{70,000}=0.22$ rep. tion. The rates of albumin synthesis and degradation were assumed to be equal. No subject had significant proteinuria. Lugol's solution (15 drops daily) was given two days prior to and during the studies. This iodine prefeeding was intended to prevent thyroid uptake and promote excretion of $I^{121}$ liberated on degradation of the iodo-albumin. External surveys over the thyroid gland confirmed that no significant thyroid uptake occurred.? In two subjects not given Lugol's solution, however, the disappearance curves did not differ from the rest of the group.

After intravenous injection of 1 to $10 \mathrm{mg}$. of labelled protein, blood samples were drawn in heparinized syringes. Samples were taken over a two week period for turnover studies, usually on alternate days. In six special studies to obtain complete curves, additional short term samples were taken 10 minutes, 30 minutes, two hours, six hours, and 24 hours after injection, and 24 hour urine collections were made for seven days.

\section{RESULTS AND INTERPRETATIONS}

The injection of $\mathrm{I}^{131}$-tagged albumin was followed by a relatively rapid initial fall in plasma

7 Done in cooperation with Dr. Donald S. Frederickson.

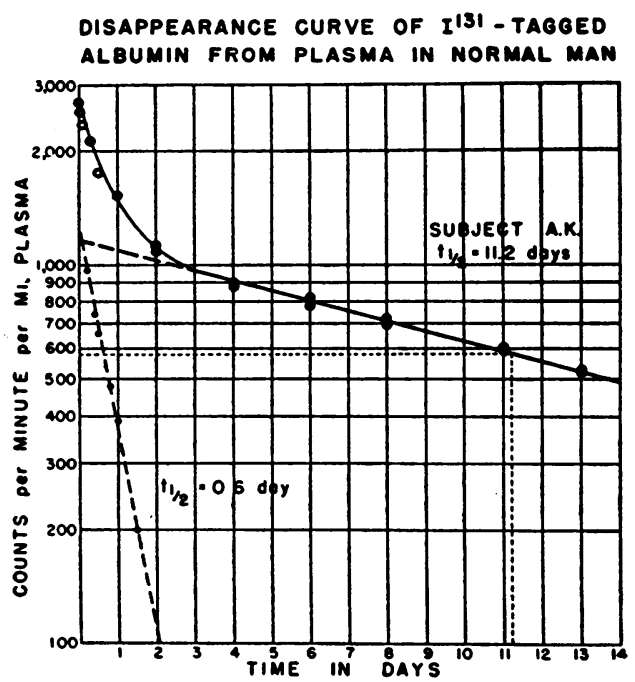

FIG. 5

Semi-logarithmic plot. The observed values for plasma radioactivity are recorded as circles through which is drawn the solid line, showing a rapid initial fall and more gradual (linear) decline after two days. This experimental curve has been resolved into two straight line components.

The rapid component is attributed to distribution of the labelled protein in the "exchangeable albumin pool." The slow component is considered to represent metabolic degradation of the iodo-albumin. The half-time $\left(t_{1 / 2}\right)$ of this albumin turnover is obtained graphically as shown by the horizontal and vertical dotted lines. 
TABLE I

Albumin turnover data in 21 normal male medical students

\begin{tabular}{|c|c|c|c|c|c|c|c|c|c|c|c|}
\hline \multirow{2}{*}{ Subject } & \multirow{2}{*}{$\begin{array}{l}\text { Wt. } \\
\text { (kg.) }\end{array}$} & \multirow{2}{*}{$\begin{array}{c}\text { Surface } \\
\text { area } \\
\left(m^{2}\right)\end{array}$} & \multirow{2}{*}{$\underset{\substack{\text { Serum } \\
\text { (grams \% })}}{\text { glbumin }}$} & \multirow{2}{*}{$\begin{array}{c}\text { Exchange- } \\
\text { able } \\
\text { albumin } \\
\text { pool } \\
\text { (grams) }\end{array}$} & \multirow{2}{*}{$\begin{array}{l}\text { Albumin/ } \\
\text { (body. }\end{array}$} & \multirow{2}{*}{$\begin{array}{c}\text { Albumin/ } \\
1.73 \mathrm{~m}^{2} \\
\text { (surface } \\
\text { area) }\end{array}$} & \multirow{2}{*}{$\begin{array}{c}\text { th } \\
\text { (half-time } \\
\text { in days) }\end{array}$} & \multicolumn{4}{|c|}{ Albumin turnover rate } \\
\hline & & & & & & & & $\% /$ day & $\underset{\text { day }}{\text { Grams/ }}$ & $\begin{array}{l}\text { Grams/ } \\
\text { kg./day }\end{array}$ & $\begin{array}{c}\text { Grams/ } \\
1.73 \mathrm{~m}^{2} / \mathrm{day}\end{array}$ \\
\hline $\begin{array}{l}\text { B. K. } \\
\text { E. H. } \\
\text { J. W. } \\
\text { J.P. } \\
\text { W. J. K. } \\
\text { J. G. C. } \\
\text { G.C. } \\
\text { J.H. } \\
\text { W. B. K. } \\
\text { W. H. } \\
\text { E. C. } \\
\text { T. D. } \\
\text { N. C. } \\
\text { O. D. } \\
\text { F. H. } \\
\text { P.S. } \\
\text { A. K. } \\
\text { F. P. } \\
\text { R. G. } \\
\text { W. K. } \\
\text { D. M. }\end{array}$ & $\begin{array}{r}75.0 \\
83.2 \\
76.4 \\
68.2 \\
63.6 \\
72.7 \\
75.0 \\
51.0 \\
86.5 \\
69.0 \\
68.3 \\
82.0 \\
72.7 \\
100.0 \\
77.3 \\
70.5 \\
70.5 \\
73.7 \\
75.0 \\
65.9 \\
80.9\end{array}$ & $\begin{array}{l}1.93 \\
2.03 \\
1.99 \\
1.90 \\
1.80 \\
1.92 \\
1.94 \\
1.55 \\
2.11 \\
1.85 \\
1.86 \\
1.96 \\
1.93 \\
2.23 \\
2.03 \\
1.92 \\
1.90 \\
1.88 \\
1.94 \\
1.86 \\
2.01\end{array}$ & $\begin{array}{l}4.6 \\
4.8 \\
4.2 \\
4.6 \\
4.4 \\
4.7 \\
4.3 \\
4.5 \\
4.6 \\
4.7 \\
4.5 \\
4.3 \\
4.4 \\
4.3 \\
4.5 \\
4.5 \\
4.2 \\
4.1 \\
3.7 \\
4.1 \\
5.0\end{array}$ & $\begin{array}{l}268 \\
276 \\
268 \\
253 \\
213 \\
299 \\
276 \\
227 \\
205 \\
203 \\
265 \\
175 \\
281 \\
271 \\
313 \\
281 \\
244 \\
286 \\
225 \\
268 \\
343\end{array}$ & $\begin{array}{l}3.57 \\
3.32 \\
3.51 \\
3.71 \\
3.35 \\
4.11 \\
3.68 \\
4.45 \\
2.37 \\
2.94 \\
3.88 \\
2.14 \\
3.86 \\
2.71 \\
4.05 \\
3.99 \\
3.46 \\
3.88 \\
3.00 \\
4.07 \\
4.24\end{array}$ & $\begin{array}{l}240 \\
235 \\
233 \\
230 \\
205 \\
269 \\
246 \\
253 \\
168 \\
190 \\
247 \\
155 \\
252 \\
210 \\
267 \\
253 \\
222 \\
263 \\
201 \\
249 \\
295\end{array}$ & $\begin{array}{r}9.1 \\
8.2 \\
9.5 \\
9.2 \\
8.7 \\
11.6 \\
11.4 \\
12.4 \\
9.8 \\
9.2 \\
12.2 \\
9.0 \\
11.2 \\
9.7 \\
12.0 \\
11.6 \\
11.2 \\
11.4 \\
9.2 \\
13.4 \\
11.2\end{array}$ & $\begin{array}{l}7.62 \\
8.45 \\
7.30 \\
7.53 \\
7.96 \\
5.98 \\
6.08 \\
5.60 \\
7.07 \\
7.53 \\
5.68 \\
7.70 \\
6.19 \\
7.15 \\
5.77 \\
5.98 \\
6.19 \\
6.08 \\
7.53 \\
5.17 \\
6.19\end{array}$ & $\begin{array}{l}20.4 \\
23.3 \\
19.6 \\
19.0 \\
17.0 \\
17.9 \\
16.8 \\
12.7 \\
14.5 \\
15.3 \\
15.0 \\
13.5 \\
17.4 \\
19.4 \\
18.1 \\
16.8 \\
15.1 \\
17.4 \\
16.9 \\
13.9 \\
21.2\end{array}$ & $\begin{array}{l}0.272 \\
0.281 \\
0.256 \\
0.279 \\
0.267 \\
0.246 \\
0.224 \\
0.249 \\
0.168 \\
0.222 \\
0.220 \\
0.165 \\
0.239 \\
0.194 \\
0.234 \\
0.238 \\
0.214 \\
0.236 \\
0.226 \\
0.210 \\
0.262\end{array}$ & $\begin{array}{l}18.3 \\
19.9 \\
17.0 \\
17.3 \\
16.3 \\
16.1 \\
15.0 \\
14.2 \\
11.9 \\
14.3 \\
14.0 \\
11.9 \\
15.6 \\
15.0 \\
15.4 \\
15.1 \\
13.7 \\
16.0 \\
15.1 \\
12.9 \\
18.3\end{array}$ \\
\hline \multicolumn{3}{|c|}{$\begin{array}{l}\text { Mean } \\
\text { Standard deviation } \\
\text { Standard error of mean }\end{array}$} & 4.4 & $\begin{array}{r}259 \\
40 \\
9\end{array}$ & $\begin{array}{l}3.54 \\
0.61 \\
0.13\end{array}$ & $\begin{array}{r}232 \\
34 \\
7.5\end{array}$ & $\begin{array}{r}10.5 \\
1.5 \\
0.3\end{array}$ & $\begin{array}{l}6.70 \\
0.93 \\
0.02\end{array}$ & $\begin{array}{r}17.2 \\
2.7 \\
0.6\end{array}$ & $\begin{array}{l}0.233 \\
0.032 \\
0.007\end{array}$ & $\begin{array}{r}15.4 \\
2.0 \\
0.4\end{array}$ \\
\hline
\end{tabular}

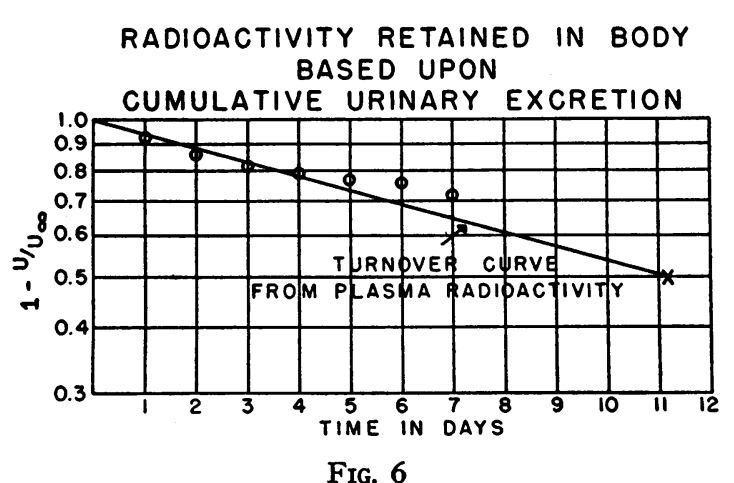

Semi-logarithmic plot. The points were obtained from radioactive assays on aliquots of 24 hour urine collections from Subject A. K.

$$
\begin{aligned}
& \mathrm{U}_{\infty}=\text { injected dose, or total urinary excretion } \\
& \text { after an infinite time on the assumption } \\
& \text { that all excretion is by the urine. } \\
& \mathrm{U}=\text { cumulative urinary excretion through a } \\
& \text { given day. }
\end{aligned}
$$

Hence $U / U_{\infty}=$ fraction excreted by a given day.

$1-\mathrm{U} / \mathrm{U}_{\infty}=$ fraction retained in the body on a given day.

The line drawn duplicates the slow component of Figure 5 for purposes of comparison. If all radioiodine from degraded iodo-albumin were excreted promptly in the urine, the points would fall on the line. The points above the line indicate retention of some liberated radioiodine or excretion by other routes. radioactivity. After approximately two days a more gradual decline occurred. This gradual decline was an exponential decay, since a semilogarithmic plot revealed that points after the second day approximated a straight line (Figure 5) in all subjects. The exponential decay was considered to represent the rate of degradation of the administered iodo-albumin, or rate of replacement of tagged by untagged albumin, hence the turnover rate of the protein.

Complete curves including the rapid initial fall (as in Figure 5) were obtained in six subjects. The experimental curve on semi-logarithmic plot was resolved into two straight line components by standard graphic analysis (14). The mean half-time of the rapid component in the six subjects was 0.5 day. This initial fall of plasma radioactivity was attributed to distribution of the labelled protein in the body's exchangeable pool of albumin, including extravascular sites. Twenty-four hour urine collections excluded urinary loss as a significant factor. The urinary recovery approximated or was less than the decline of the slow component based on points after the second day (Figure 6). The urinary non-protein organic combinations of $I^{131}(10)$ were not investigated. 
Blood samples were not taken prior to 24 hours in the remaining 15 subjects. The 24 hour point invariably and the 48 hour point usually fell above the line drawn through the remaining points.

The half-time of albumin turnover was obtained graphically from the linear plot of the slow component. The slope of the line gave the turnover rate, which may be obtained graphically, or may be computed from the expression

$$
\text { turnover rate }=\frac{\ln 2}{t_{1}}=\frac{0.693}{t_{1}} .
$$

This is derived from the equation for the exponential decay

$$
\mathrm{A}=\mathrm{A}_{0} \mathrm{e}^{-\mathbf{k t}} \text {, }
$$

where $A=I^{131}$-tagged albumin at any time

$A_{0}=I^{131}$-tagged albumin at zero time

$t=$ time in days

$\mathbf{k}=$ turnover rate as fraction of the albumin pool turned over per day. This is conveniently expressed as per cent.

TABLE II

Calculation of albumin turnover data

(Subject A. K., Figure 5)

Albumin turnover rate as \%/day

$$
\frac{0.693}{t_{i}}=\frac{0.693}{11.2 \text { days }}=0.0619=6.19 \% / \text { day }
$$

Exchangeable albumin pool

Albumin specific activity at zero time assuming
complete distribution

1160 counts $/ \mathrm{ml}$. plasma $=\frac{1160 \text { counts } / \mathrm{ml} \text {. plasma }}{42 \mathrm{mg} \text {. plam }}$ $=27.6$ counts $/ \mathrm{mg}$. albumin

By isotope dilution principle,

$\frac{6,749,000 \text { counts injected }}{(27.6 \text { counts } / \mathrm{mg} \text {. albumin }) \times 1,000}=\begin{gathered}244 \text { grams } \\ \begin{array}{c}\text { (exchangeable albu- } \\ \text { min pool })\end{array}\end{gathered}$

Albumin turnover in grams/day

244 grams $\times 6.19 \% /$ day

(exchangeable albumin pool) (turnover)

$=15.1$ grams albumin $/$ day

Approximation of circulating albumin and extravascular albumin

Albumin specific activity $\begin{aligned} & \text { at zero time assuming } \\ & \text { mixing with circulating } \\ & \text { albumin only }\end{aligned}=\frac{2760 \text { counts } / \mathrm{ml} \text {. plasma }}{42 \mathrm{mg} \text {. albumin } / \mathrm{ml} \text {. plasma }}$ $=65.7$ counts $/ \mathrm{mg}$. albumin

By isotope dilution principle,

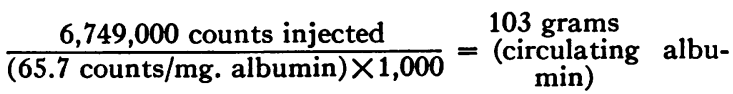

244 grams exchangeable albumin pool

-103 grams circulating albumin

141 grams extravascular albumin
TABLE III

Distribution of albumin between vascular and extravascular sites

\begin{tabular}{l|c|c|c|c}
\hline \hline Subject & $\begin{array}{c}\text { Exchange- } \\
\text { able } \\
\text { albumin } \\
\text { pool } \\
\text { (grams) }\end{array}$ & $\begin{array}{c}\text { Circu- } \\
\text { lating } \\
\text { albumin } \\
\text { (grams) }\end{array}$ & $\begin{array}{c}\text { Extra- } \\
\text { vascular } \\
\text { albumin } \\
\text { (grams) }\end{array}$ & $\begin{array}{c}\text { Ratio } \\
\text { exchangeable albumin pool } \\
\text { circulating albumin/ }\end{array}$ \\
\hline W. J. K. & 213 & 121 & 92 & 0.57 \\
A. K. & 244 & 103 & 141 & 0.42 \\
F. P. & 286 & 132 & 154 & 0.46 \\
R. G. & 225 & 106 & 119 & 0.47 \\
W. K. & 268 & 95 & 173 & 0.35 \\
D. M. & 343 & 143 & 200 & 0.42 \\
\hline
\end{tabular}

In the group of 21 normal subjects (Table I) the mean half-time of albumin turnover was 10.5 $\pm 1.5^{8}$ days. The mean albumin turnover rate was $6.7 \% \pm 0.93 \%$ per day.

The "exchangeable albumin pool" was obtained by the isotope dilution formula, using the zero time extrapolation of the slow component (Table II). The mean value for exchangeable albumin pool was $259 \pm 40$ grams. This quantity was considered to signify the albumin in the body, intraand extravascular, with which the labelled protein mixed.

The product of the exchangeable albumin pool and the turnover rate in per cent gave the turnover in grams of albumin per day. The mean of the series was $17.2 \pm 2.7$ grams per day. Most of the medical students were larger than the hypothetical average $70 \mathrm{~kg}$. male with $1.73 \mathrm{~m}^{2}$ surface area. Expressions were therefore computed in terms of body weight and surface area. The mean value for the latter was $15.4 \pm 2.0$ grams per $1.73 \mathrm{~m}^{2}$ per day.

As an adjunct to the above results, estimations were made of the distribution of albumin between the circulating plasma and extravascular sites. In the six subjects in whom 10 and 30 minute plasma samples were taken, it was possible to obtain an approximation of the circulating albumin (Table II). The isotope dilution formula was applied, using the zero time extrapolation of a line through the short term points. The results indicated the same order of magnitude for intraand extravascular albumin (Table III).

This rough conformity was evident from inspection of the graphs (Figure 5) which revealed that

$8 \pm$ signifies standard deviation from the mean. 
the rapid phase ended in the vicinity of the $50 \%$ level.

\section{DISCUSSION}

The validity of the iodo-albumin measurement of turnover rate depends upon the accuracy of the underlying assumptions of stability of tagging and normal metabolic behavior in vivo. Support for these assumptions is provided by the disappearance curves of $\mathrm{I}^{131}$-tagged human albumin in rabbits observed by previous investigators $(7,9$, 10) and in the present work. Close resemblance of disappearance rates of labelled and untreated human proteins in a foreign species suggests such resemblance in the human. Similar disappearance rates of iodinated homologous and heterologous proteins, have been reported $(10,15)$. Wasserman and Mayerson (15) observed no significant differences between $\mathrm{I}^{131}$-tagged human and canine albumins injected intravenously into dogs.

A further suggestion that labelling with a few iodine atoms per molecule does not significantly alter biologic characteristics is provided by the work of Sonenberg (16), in which iodinated protein hormones of the anterior pituitary (ACTH, prolactin, etc.) were found to retain their endocrine activity.

The conclusive proof of these assumptions will require further work, possibly including experiments with double labelling of proteins.

It was of practical importance to test individual lots of iodo-albumin for evidence of alteration from the native state. In this respect ultracentrifugal analysis was the most sensitive criterion that the labelled albumin was not significantly changed from the starting material. Electrophoresis is not a satisfactory substitute, as electrophoretic mobility is often not affected by minor degrees of molecular aggregation. Proteins showing significant alteration on ultracentrifugal analysis have exhibited abnormally rapid disappearance curves.

Plasma proteins or albumin labelled with radioactive iodine have long been used for human plasma volume estimations $(17,18)$, but observations on disappearance rates beyond 24 hours have not been reported in human subjects.

Previous clinical investigations (1-3) have been concerned with the metabolic fate of massive in- travenous infusions of concentrated albumin. Eckhardt and associates (2) estimated a mean half-time of about five days for albumin administered to normal and undernourished subjects. Such work, however, deals with a problem distinctly separate from albumin turnover in a steady state. Massive albumin infusions sufficient to produce an appreciable rise of serum albumin concentration are not comparable to the injection of 1 to $10 \mathrm{mg}$. of albumin, which could not affect the subject's metabolism.

In the present work the serum albumin values were essentially the same at the beginning and end of the studies. The subjects were therefore considered to be in a steady state with respect to serum albumin concentration. The rates of synthesis and degradation were assumed to be equal; the albumin turnover thus signified both rates.

Tracer experiments similar to the present approach but with different labels afford some basis for comparison. Biosynthesis of proteins containing the isotopes $\mathrm{N}^{15}, \mathrm{~S}^{35}$, and $\mathrm{C}^{14}$ has been undertaken, so that the label is an integral part of the protein molecule. This would appear a priori to be the method of choice, since it avoids uncertainties as to firmness of tagging and normal biochemical properties in vivo, which may be raised regarding any extrinsic tag such as $\mathrm{I}^{131}$.

There is, however, an important objection or qualification to the studies with intrinsic isotopic labels that have thus far been undertaken in human subjects. In $\mathrm{N}^{15}$ studies, for example, the isotope was fed for two days as a labelled amino acid. The isotope concentration in the plasma proteins rose rapidly, then fell as soon as isotope administration was discontinued. The rate of decline was used to compute turnover rate. As pointed out by Rittenberg (19) such an analysis depends upon the assumptions of

(1) infinitely rapid mixing of liberated amino acids into

(2) an infinitely large metabolic pool of negligible isotope concentration.

In other words, the analysis neglects the synthesis of new isotopic plasma proteins out of labelled amino acids from degraded plasma protein or from the nitrogen pool, including other body 
proteins labelled during isotope feeding. Insofar as this factor operates, the half-time obtained by such experiments will be falsely long. Future investigations may eliminate or correct for this uncertainty, but it exists in the material reported thus far.

Although a completed study on $\mathrm{N}^{15}$ plasma protein turnover has not as yet appeared, London's preliminary presentation (20) is of interest. Data on protein turnover in a normal man and a normal woman were interpreted to indicate a half-time for serum albumin of 20 days. As qualified above, this figure would represent an upper limit, and may probably be viewed as within the general range of the present findings.

The data of Kinsell and coworkers (21) with $\mathrm{S}^{35}$ methionine were not subjected to analysis based on exponential decay. Beyond noting a gross resemblance, comparison is difficult.

Bovine albumin was administered intravenously to human subjects on an experimental basis by Heyl and Janeway (22) during World War II. Disappearance curves determined by immunochemical tests were quite similar to those of the present report, including the rapid fall in the first day or two.

The rapid initial fall has invariably been observed in previous studies $(7,9,10,22)$ with injected labelled proteins as well as with heterologous proteins "labelled" only with respect to their antigenic characteristics. This was the case in the experiments on dogs by Whipple's group (23) with plasma proteins bearing an intrinsic label, $\mathrm{C}^{14}$-lysine. Therefore, an artefact of tagging, such as preferential utilization of the labelled protein, would appear unlikely as a significant factor in the early rapid phase of the disappearance curve. Rather, the observations are compatible with distribution of labelled protein in an exchangeable pool including extravascular albumin. Wasserman and Mayerson (15) offer direct evidence in support of this interpretation based upon the appearance of iodo-albumin in the lymph of dogs simultaneously with its disappearance from the plasma. With attainment of equilibrium, the specific activity of albumin became equal in plasma and lymph, and remained so, indicating uniform distribution of the tagged protein.

The present study was not intended to determine accurately the distribution of the exchange- able albumin pool among body compartments. The exchangeable pool presumably consists of albumin in circulating plasma and in extravascular sites. The latter may possibly include albumin within cells as well as the albumin of the lymph and interstitial fluid. Approximations of the intra- and extravascular albumin from the present data (Table. III) indicated that these two quantities were of the same order of magnitude in the normal human. Comparable results have been reported in dogs $(15,23 a)$.

If the values for extravascular albumin (Table III) be divided by hypothetical interstitial fluid volumes assigned $15 \%$ of the body weights, an average of 1.4 grams $\%$ is obtained as the mean albumin concentration of all the interstitial fluid including the lymph. This figure seems plausible (24) because the total protein concentration of interstitial fluid probably ranges from about 0.3 gram \% for capillary filtrate (25) to as much as 4.5 to 5.6 grams $\%$ for fully elaborated lymph in the cervical region and liver respectively (26$29,24)$. The figure of 1.4 grams $\%$ would be falsely high to the extent that interstitial fluid albumin may be in equilibrium with albumin in cells. The possibility of reversible penetration of cells by intact albumin would not invalidate the assumptions of the present work; such protein within cells would be considered part of the extravascular pool.

Janeway's and Heyl's (22) comparative studies of the disappearance of crystalline bovine albumin in different species revealed progressively slower rates in rabbit, dog, and man respectively. A similar relation probably exists for the turnover rates of the homologous proteins. Comparative $\mathrm{N}^{15}$ studies (30) have revealed five times as rapid a mean rate of protein synthesis in the rat as in man. The species difference, therefore, precludes exact comparison of the present findings with the study on rats by Abdou and Tarver (31) or the work on dogs by Whipple's group (23). However, fundamental agreement in terms of the general picture is apparent.

\section{SUMMARY}

1. The turnover rate of human albumin was studied by following the disappearance of intravenously administered $I^{131}$-tagged albumin in 1 to 
$10 \mathrm{mg}$. doses which did not affect the subject's metabolism.

2. Albumin labelled with $2-3$ iodine atoms per molecule remained tagged after intravenous injection in rabbits and behaved like native protein by immunochemical tests.

3. Human subjects received Lugol's solution preceding and throughout studies to inhibit thyroid uptake and promote excretion of radioiodine liberated on degradation of administered iodo-albu$\min$.

4. On adequate dietary intake the serum albumin concentration and body weight remained relatively stable. Steady state conditions were assumed and the turnover rate was considered to signify rates of synthesis and degradation.

5. The exponential fall in plasma radioactivity after the second day was considered to represent the rate of degradation of the administered iodoalbumin, or rate of replacement of tagged by untagged albumin, hence the turnover rate of the protein.

6. The "exchangeable albumin pool" was calculated by the isotope dilution principle.

7. The product of the exchangeable albumin pool and turnover rate yielded turnover of albumin in grams per day.

8. In 21 normal male medical students the following mean values were obtained:

Exchangeable albumin pool

$$
\begin{aligned}
& 259 \pm 40 \text { grams } \\
& 232 \pm 34 \text { grams } / 1.73 \mathrm{~m}^{2} \text { (surface area) }
\end{aligned}
$$

\section{Half-time}

$$
10.5 \pm 1.5 \text { days }
$$

\section{Albumin turnover rate}

$$
\begin{aligned}
& 6.7 \% \pm 0.93 \% / \text { day } \\
& 17.2 \pm 2.7 \text { grams } / \text { day } \\
& 15.4 \pm 2.0 \text { grams } / 1.73 \mathrm{~m}^{2} / \text { day. }
\end{aligned}
$$

9. In six normal subjects approximations of the intra- and extravascular albumin of the body indicated these quantities were of the same order of magnitude.

\section{ACKNOWLEDGMENTS}

Appreciation is due Drs. J. L. Oncley, A. Baird Hastings, S. J. Gray, and A. K. Solomon for advice and guidance, Drs. E. M. Landis and I. S. Edelman for help- ful criticism, and Drs. D. Gitlin and E. H. Kass for suggestions on immunochemical technique. Harold A. Papazian, Madison B. Whittier and Richard Cohen rendered valuable technical assistance.

\section{REFERENCES}

1a. Thorn, G. W., Armstrong, S. H., Jr., Davenport, V. D., Woodruff, L. M., and Tyler, F. H., Chemical, clinical, and immunological studies on the products of human plasma fractionation. XXX. The use of salt-poor concentrated human serum albumin solution in the treatment of chronic Bright's disease. J. Clin. Invest., 1945, 24, 802.

b. Thorn, G. W., Armstrong, S. H., Jr., and Davenport, V. D., Chemical, clinical, and immunological studies on the products of human plasma fractionation. XXXI. The use of salt-poor concentrated human serum albumin solution in the treatment of hepatic cirrhosis. J. Clin. Invest., 1946, 25, 304.

2. Eckhardt, R. D., Lewis, J. H., Murphy, T. L., Batchelor, W. H., and Davidson, C. S., Chemical, clinical, and immunological studies on the products of human plasma fractionation. XXXIV. Comparative studies on the nutritive value of orally and intravenously administered human serum albumin in man. J. Clin. Invest., 1948, 27, 119.

3. Albright, F., Forbes, A. P., Bartter, F. C., Reifenstein, E. C., Jr., Bryant, D., Cox, L. D., and Dempsey, E. F., Studies on the fate of intravenously administered human plasma proteins in idiopathic hypoproteinemia and in osteoporosis, in: Symposia on Nutrition, Vol. II, Plasma Proteins. The Robert Gould Research Foundation, Inc. Charles C Thomas, Springfield, Ill., 1950.

4. Hughes, W. L., Jr., and Straessle, R., Preparation and properties of serum and plasma proteins. XXIV. Iodination of human serum albumin. J. Am. Chem. Soc., 1950, 72, 452.

5. Latta, H., Experimental hypersensitivity in the rabbit. Blood and tissue concentrations of foreign proteins labeled with radioactive iodine and injected intravenously. J. Immunol., 1951, 66, 635.

6. Eisen, H. N., and Keston, A. S., The immunologic reactivity of bovine serum albumin labelled with trace-amounts of radioactive iodine $\left(\mathrm{I}^{121}\right)$. J. Immunol., 1949, 63, 71.

7. Knox, W. C., and Endicott, F. C., $I^{120}$ as an antigen label in the circulating serum of non-immune rabbits. J. Immunol., 1950, 65, 523.

8. Gitlin, D., Use of ultraviolet absorption spectroscopy in the quantitative precipitin reaction. J. Immunol., 1949, 62, 437.

9. Gitlin, D., Latta, H., Batchelor, W. H., and Janeway, C. A., Experimental hypersensitivity in the rabbit. Disappearance rates of native and labelled heterologous proteins from the serum after intravenous injection. J. Immunol., 1951, 66, 451. 
10. Dixon, F. J., Bukantz, S. C., and Dammin, G. J., The effect of sensitization and X-radiation on the metabolism of $I^{121}$ labeled proteins. Science, 1951, 113, 274.

11. Gray, S. J., and Sterling, K., The tagging of red cells and plasma proteins with radioactive chromium. J. Clin. Invest., 1950, 29, 1604.

12. Robinson, C. V., Windowless, flow type, proportional counter for counting $\mathrm{C}^{14}$. Science, 1950, 112, 198.

13a. Marinelli, L. D., Quimby, E. H., and Hine, G. J., Dosage determination with radioactive isotopes. II. Practical considerations in therapy and protection. Am. J. Roentgenol., 1948, 59, 260.

b. Marinelli, L. D., Dosage determination in the use of radioactive isotopes. J. Clin. Invest., 1949, 28, 1271.

14. Solomon, A. K., Equations for tracer experiments. J. Clin. Invest., 1949, 28, 1297.

15. Wasserman, K., and Mayerson, H. S., Exchange of albumin between plasma and lymph. Am. J. Physiol., 1951, 165, 15.

16a. Sonenberg, M., Keston, A. S., and Money, W. L., Studies with labelled anterior pituitary preparations: adrenocorticotropin. Endocrinology, 1951, 48, 148.

b. Sonenberg, M., Personal communication.

17. Fine, J., and Seligman, A. M., Traumatic shock. VII. A study of the problem of the "lost plasma" in hemorrhagic tourniquet and burn shock by the use of radioactive iodo-plasma proteins. J. Clin. Invest., 1944, 23, 720.

18. Crispell, K. R., Porter, B., and Nieset, R. T., Studies of plasma volume using human serum albumin tagged with radioactive iodine ${ }^{12}$. J. Clin. Invest., 1950, 29, 513.

19. Rittenberg, D., The application of the isotope technique to the study of the metabolism of glycine. Cold Spring Harbor Symposia on Quantitative Biology. Cold Spring Harbor, N. Y., 1948, 13, 173.

20. London, I. M., Studies on the rates of formation of serum proteins in man, in: Symposia on Nutrition, Vol. II, Plasma Proteins. The Robert Gould Research Foundation, Inc. Charles C Thomas, Springfield, IIl., 1950.
21. Kinsell, L. W., Margen, S., Tarver, H., Frantz, J. McB., Flanagan, E. K., Hutchin, M. E., Michaels, G. D., and McCallie, D. P., Studies in methionine metabolism. III. The fate of intravenously administered $\mathrm{S}^{25}$-labeled-methionine in normal adult males, in patients with chronic hepatic disease, "idiopathic" hypoproteinemia and Cushing's syndrome. J. Clin. Invest., 1950, 29, 238.

22. Janeway, C. A., Personal communication.

23a. Miller, L. L., Bale, W. F., Yuile, C. L., Masters, R. E., Tishkoff, G. H., and Whipple, G. H., The use of radioactive lysine in studies of protein metabolism. J. Exper. Med., 1949, 90, 297.

b. Yuile, C. L., Lamson, B. G., Miller, L. L., and Whipple, G. H., Conversion of plasma protein to tissue protein without evidence of protein breakdown; results of giving plasma protein labeled with carbon $^{14}$ parenterally to dogs. J. Exper. Med., 1951, 93, 539.

24. Landis, E. M., Personal communication.

25. Landis, E. M., Capillary permeability and the factors affecting the composition of capillary filtrate. Ann. New York Acad. Sc., 1946, 46, 713.

26. Drinker, C. K., and Field, M. E., Lymphatics, Lymph and Tissue Fluid. The Williams \& Wilkins Co., Baltimore, Md., 1933.

27. Drinker, C. K., and Yoffey, J. M., Lymphatics, Lymph and Lymphoid Tissue: Their Physiological and Clinical Significance. Harvard Univ. Press, Cambridge, Mass., 1941.

28. McCarrell, J. D., Thayer, S., and Drinker, C. K., The lymph drainage of the gall bladder together with observations on the composition of liver lymph. Am. J. Physiol., 1941, 133, 79.

29. Nix, J. T., Mann, F. C., Bollman, J. L., Grindlay, J. H., and Flock, E. V., Alterations of protein constituents of lymph by specific injury to the liver. Am. J. Physiol., 1951, 164, 119.

30. Sprinson, D. B., and Rittenberg, D., The rate of interaction of the amino acids of the diet with the tissue proteins. J. Biol. Chem., 1949, 180, 715.

31. Abdou, I. A., and Tarver, H., Plasma protein. I. Loss from circulation and catabolism to carbon dioxide. J. Biol. Chem., 1951, 190, 769. 